\section{Comment}

Phaeochromocytoma presenting as a cardiac or abdominal emergency has been described in adults but is less common in children. All 85 children reviewed by Hume had symptoms for at least two weeks, although in several of the children the condition ran a rapid course and was not diagnosed until sudden death occurred. ${ }^{4}$ Minor trauma and surgery are common precipitants of symptoms in phaeochromocytoma, and deliberate massage of the tumour by a physician may provoke an attack.

Our patient was examined by several different doctors, which may have caused sustained release of catecholamines. More probably, however, an appreciable discharge at the time of the initial trauma produced a catecholamine crisis. A phaeochromocytoma might have been suspected if more weight had been given to the initial hypertension and persistent dilated pupils. Although treatment with $\alpha$ and $\beta$ adrenergic blockade might have reversed the outcome, the myocardial injury caused by the initial release of the catecholamine may have been too advanced at presentation for this to have been of any great benefit.

We thank Mr J A S Dickson and Professor R D G Milner for permission to publish the clinical details of this case. We also thank Miss J Massey for carrying out the catecholamine assays.

I Stringel G, Ein SH, Creighton R, Daneman D, Howard N, Filler RM. Pheochromocytoma in children-an update. F Pediatr Surg 1980;15:496-500.

2 Jelliffe RS. Phaeochromocytoma presenting as a cardiac and abdominal catastrophe. Br Med $\mathcal{F}$ 1952;ii:76-7.

3 Vallance WB. Sudden death from an asymptomatic phaeochromocytoma. Br Med $\mathcal{F}$ 1957;i:686-7. 4 Hume DM. Pheochromocytoma in the adult and in the child. Am f Surg 1960;99:458-96.

5 Symington T. Functional pathology of the human adrenal gland. Edinburgh: Livingstone, 1969: $286-7$.

(Accepted 14 October 1985)

Children's Hospital, Sheffield S10 2TH

R A PRIMHAK, MB, MRCP, lecturer in paediatrics

R D SPICER, MB, FRCS, senior surgical registrar

$S$ VARIEND, MD, MRCPATH, consultant histopathologist

Correspondence to: Dr Primhak.

but responded to verbal commands, had pinpoint pupils, and was sweating and

\title{
Opiate toxicity after self poisoning with aspirin and codeine
}

Compound analgesic preparations containing aspirin and codeine have been widely available for many years, but to our knowledge there is no record of serious toxicity in adults from any component other than salicylate. We report on two patients who developed severe opiate toxicity after overdoses of aspirin and codeine tablets $B P$ (aspirin $300 \mathrm{mg}$, codeine $8 \mathrm{mg}$ ).

\section{Case reports}

CASE 1

A 34 year old woman was admitted four hours after having ingested 80 tablets (24 $\mathrm{g}$ aspirin, $640 \mathrm{mg}$ codeine) with $100 \mathrm{mg}$ metoclopramide and alcohol. On examination she was unresponsive to painful stimuli, had pinpoint pupils, and was sweating. Her pulse rate was $130 / \mathrm{min}$ and blood pressure $115 / 80 \mathrm{~mm} \mathrm{Hg}$, and respiration was shallow at a rate of $38 / \mathrm{min}$. Arterial blood gas analysis showed a mixed metabolic and respiratory acidosis $(\mathrm{pH} 7 \cdot 24$, carbon dioxide tension $5 \cdot 9$ $\mathrm{kPa}(44 \mathrm{~mm} \mathrm{Hg})$, oxygen tension $10.2 \mathrm{kPa}(77 \mathrm{~mm} \mathrm{Hg})$, and bicarbonate 18.9 $\mathrm{mmol}(\mathrm{mEq}) / \mathrm{l})$. After administration of naloxone $(0.8 \mathrm{mg}$ intravenously) her conscious level improved such that she responded to verbal commands, the pupils dilated, and the respiratory component of the acidosis was reversed within 30 minutes $(\mathrm{pH} \mathrm{7.4}$, carbon dioxide tension $2.8 \mathrm{kPa}(21 \mathrm{~mm} \mathrm{Hg})$, oxygen tension $14 \cdot 1 \mathrm{kPa}(106 \mathrm{~mm} \mathrm{Hg})$, and bicarbonate $14 \mathrm{mmol} / \mathrm{l}$. A further $1.2 \mathrm{mg}$ naloxone was given to prevent deterioration of conscious level.

Plasma salicylate and codeine concentrations on admission were $1083 \mathrm{mg} / \mathrm{l}$ and $590 \mu \mathrm{g} / \mathrm{l}$ respectively. Plasma urea, sodium, potassium, and glucose concentrations were normal, and the blood alcohol concentration was $47 \mathrm{mmol} / \mathrm{l}$ $(2 \cdot 15 \mathrm{~g} / \mathrm{l})$. Forced alkaline diuresis with 8 litres of a solution of isotonic saline and dextrose containing $37.5 \mathrm{mmol}(3.2 \mathrm{~g})$ sodium bicarbonate followed by 0.5 litre $1 \cdot 26 \%$ sodium bicarbonate caused the plasma salicylate concentration to fall to $508 \mathrm{mg} / \mathrm{l}$ (figure). She thereafter made an uneventful recovery and was discharged home after psychiatric review.

CASE 2

A 30 year old woman was admitted after having ingested 100 tablets $(30 \mathrm{~g}$ aspirin, $800 \mathrm{mg}$ codeine) and an unknown amount of diazepam. She was drowsy hyperventilating with a pulse rate of $115 / \mathrm{min}$ and blood pressure of $120 / 80 \mathrm{~mm}$ $\mathrm{Hg}$. Arterial blood gas analysis showed a mixed respiratory alkalosis and metabolic acidosis $\mathrm{pH} 7 \cdot 4$, carbon dioxide tension $3 \cdot 1 \mathrm{kPa}(23 \mathrm{~mm} \mathrm{Hg})$, oxygen tension $13.6 \mathrm{kPa}(102 \mathrm{~mm} \mathrm{Hg})$, and bicarbonate $15 \mathrm{mmol} / \mathrm{l}$. Immediately after administration of naloxone $(0.8 \mathrm{mg}$ intravenously) the pupils dilated and she became fully conscious. Plasma salicylate and codeine concentrations were $1006 \mathrm{mg} / \mathrm{l}$ and $650 \mu \mathrm{g} / \mathrm{l}$ respectively. Plasma urea, sodium, and potassium concentrations were normal. Diazepam and nordiazepam concentrations were $0.38 \mathrm{mg} / \mathrm{l}$ and $0.84 \mathrm{mg} / \mathrm{l}$ respectively. Forced alkaline diuresis with 6 litres of a solution similar to that used in case 1 with 1.5 litres $1.26 \%$ sodium bicarbonate was carried out; 21 hours after her admission the plasma salicylate concentration measured $462 \mathrm{mg} / \mathrm{l}$ (figure

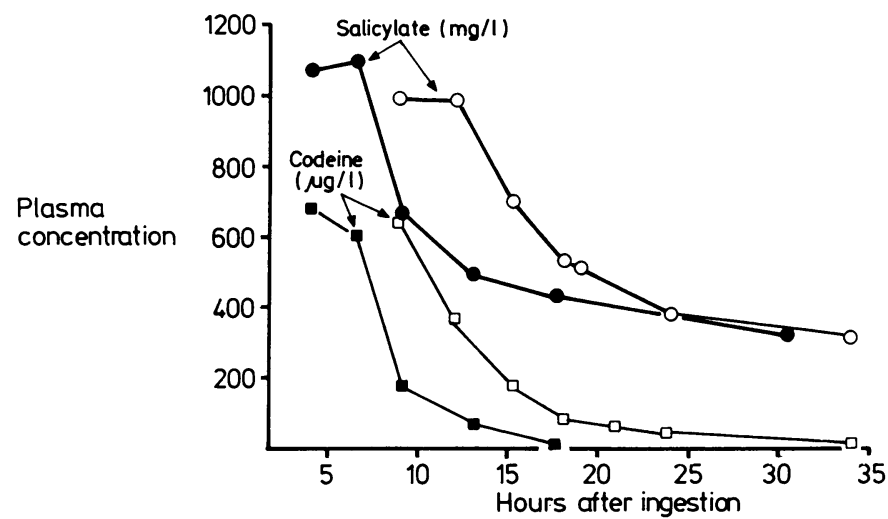

Salicylate and codeine concentrations in cases 1 (black circles and squares) and 2 (open circles and squares).

On three occasions during forced alkaline diuresis her conscious level deteriorated such that she responded only to painful stimuli and had pinpoint pupils. On each occasion these signs were reversed by naloxone, a further $4.0 \mathrm{mg}$ in total being given intravenously.

\section{Comment}

The amount of codeine in combination analgesics available without prescription is generally considered to be toxicologically unimportant in the context of overdosage. ${ }^{1}$ In both our cases, however, severe salicylate poisoning was associated with appreciable depression of consciousness and miosis, which were rapidly reversed by naloxone. Furthermore, if the central depression had been attributed solely to intoxication with salicylate haemodialysis might have been inappropriately begun because of the poor prognosis of coma induced by salicylate.

The initial plasma codeine concentrations were some five times the peak concentrations reached one hour after a $60 \mathrm{mg}$ oral dose in volunteers ${ }^{3}$ but considerably less than those reported after fatal overdose complicating abuse of narcotics $(1400-4800 \mu \mathrm{g} / \mathrm{l}) .^{45}$

Appreciable opiate toxicity may therefore complicate large overdoses of proprietary preparations containing salicylate and codeine that are widely available over the counter. Depression of consciousness after ingestion of these combination analgesics should not be attributed to salicylate acidaemia without a trial of naloxone in adequate dosage.

We thank Dr B Widdop and Dr S Dawling, poisons unit, Guy's Hospital, London, for measuring the plasma concentrations of codeine, diazepam, and nordiazepam.

1 Proudfoot AT. Salicylates and salicylamides. In: Haddad LM, Winchester JF, eds. Clinical management of poisoning and drug overdose. Philadelphia: WB Saunders, 1983:575-86.

Proudfoot AT. Toxicity of salicylates. Am f Med 1983;75(5A):99-103.

3 Findlay JWA, Jones EC, Butz RF, Welch RM. Therapeutic oral doses of codeine containing anday JWA, Jones EC, Butz RF, Welch RM.

analgesics. Clin Pharmacol Ther 1978;24:60-8.
Wright JA, Basett RC, Hine CH. Blood codeine concentrations in fatalities associated with right JA, Basett RC, Hine CH. B
codeine. Clin Toxicol 1975;8:457-63.

5 Peat MA, Sengupta S. Toxicological investigations of cases of death involving codeine and dihydrocodeine. Forensic Science 1977;9:21-32.

(Accepled 22 October 1985)

Regional Poisoning Treatment Centre, Royal Infirmary, Edinburgh EH3 9YW P J LESLIE, BSC, MRCP, senior house officer E H DYSON, MA, MRCP, registrar

A T PROUDFOOT, BSC, FRCPED, consultant

Correspondence to: Dr P J Leslie, Department of Medicine, Ninewells Hospital, Dundee DD1 9SY. 